Hydrol. Earth Syst. Sci., 12, 1075-1085, 2008

www.hydrol-earth-syst-sci.net/12/1075/2008/

(C) Author(s) 2008. This work is distributed under

the Creative Commons Attribution 3.0 License.

\title{
Projeto Vida no Vale: universal access to water and sanitation in the North East of Minas Gerais (Brazil)
}

\author{
L. Kauark-Leite ${ }^{1}$, B. Vinçon-Leite ${ }^{2}$, J. F. Deroubaix ${ }^{2}$, A. Loireau ${ }^{1}$, D. Silveira ${ }^{1}$, and E. Haddad ${ }^{3}$ \\ ${ }^{1}$ Secretaria de Estado de Planejamento e Gestão (SEPLAG), Belo Horizonte, Minas Gerais, Brazil \\ ${ }^{2}$ Université Paris-Est - CEREVE, Ecole Nationale des Ponts et Chaussées, 6 Av. Blaise Pascal, 77455 Marne la Vallée, France \\ ${ }^{3}$ Companhia de Saneamento de Minas Gerais (COPASA), Belo Horizonte, Minas Gerais, Brazil
}

Received: 23 July 2007 - Published in Hydrol. Earth Syst. Sci. Discuss.: 28 August 2007

Revised: 22 May 2008 - Accepted: 20 June 2008 - Published: 5 August 2008

\begin{abstract}
In the rural areas of the developing countries, the access to water supply and sanitation services is still largely inadequate. Poor governance of the water sector is frequently singled out as a cause and reforms are required. Studies analyzing the great diversity of restructuring efforts currently being undertaken in the water sector have not succeeded in determining the most appropriate institutional and economic framework for such reforms. Moreover they underline the lack of documentation on actual projects and call for concrete models and tools for improving water and sanitation services (WSS) and for adapting water utility practice to real conditions. In this context, the Vida no Vale (Life in the Valley) project is aimed at bringing universal access to WSS for all inhabitants of both urban and rural areas, in the northeastern area of the Brazilian State of Minas Gerais. The project takes sustainable development as its guiding principle, and relies on the joint implementation of an innovative technical design, a governance model involving public participation and subsidiarity, and an economic structure combining financial viability and social equity. Designed at a consistent geographical and hydrological scale, it includes the creation of a regional subsidiary of the existing state water company as a keystone element. The institutional organisation also relies on the creation of a public board consisting of the 92 municipalities of the project region and of the State of Minas Gerais. This board will be in charge of the system's governance. This paper presents the first step of the project (2006), consisting of a feasibility study and the implementation of 9 pilot subprojects. During the feasibility study, the supply, demand and capacity to pay for water services were defined, existing
\end{abstract}

Correspondence to: B. Vinçon-Leite (bvl@cereve.enpc.fr) infrastructure appraised, the necessary amount of investment assessed and an innovative operational model and a sustainable management system, including civil society participation, defined. The main features of the Vida no Vale project have been tested in 9 pilot sub-projects, and implemented in municipalities chosen for their low Human Development Index and for the lack of WSS, in both urban and rural areas. A second phase corresponding to the project's final implementation will run from 2007 to 2011. The Vida no Vale project design resulted in a logical and extensive framework which could be used for developing similar WSS projects in other poor, rural regions, its adaptiveness being a key feature for taking into account the specific, local conditions.

\section{Preface}

There is a broad consensus that there is widespread failure to provide basic water and sanitation services (WSS) in developing countries. During the last two decades, the international financial institutions and the research efforts concerned with finding solutions to this problem have frequently stated that the public sector alone will not be able to improve access to water and sanitation services in these countries, in the way scheduled by the United Nation Millennium Goals. As a corollary, privatization and public-private partnerships (PPP) have been largely promoted. Whatever the mechanisms, it has become obvious in recent years that results are falling far below expectation, mostly in rural areas. The project presented in this paper was born from the thoughts of Luiz Kauark-Leite. Over many years, Luiz Kauark-Leite looked for an alternative way of providing universal access to water and sanitation services for low income population

Published by Copernicus Publications on behalf of the European Geosciences Union. 
in urban and rural areas of poor Brazilian regions. In 2006, Luiz Kauark-Leite found a favourable social-political context in which to implement the Vida no Vale (Life in the Valley) project, in the North-east of the State of Minas Gerais (Brazil). Shortly before completion of the project's first phase, however, Luiz Kauark-Leite died. The duty of carrying out the Vida no Vale goals fell to his collaborators. This paper, written both by people taking part in the project and by people indirectly involved in the project as researchers in water management governance, aims at publicising the project's guiding principles and achievements. It is based on original manuscripts written by Luiz Kauark-Leite, which he did not have time to publish. The original ideas presented hereafter therefore belong to him and have been rewritten by E. Haddad, D. Silveira, A. Loireau, J.-F. Deroubaix, B. VinçonLeite in order to bring this ambitious project to the attention of a wider public. The last part of the paper tries to identify the needs of research induced by such an innovative project.

\section{Introduction}

Access to safe drinking water and basic sanitation is necessary for creating the essential conditions for improved living standards and sustainable socio-economic development. This is especially important for reducing child mortality and morbidity (UNICEF, 2006). In Brazil, it has been shown that water supply and basic sanitation services, such as the connection of households to running water and sewage services, were important factors in explaining infant mortality rates (Alves and Belluzzo, 2004). More generally, improvements in access to water and sanitation are among the main determinants of life expectancy increase in Brazil (Soares, 2007).

In adopting the Millennium Development Goals (United Nations, 2000), signatory countries pledged to halve the proportion of people without access to safe drinking water and basic sanitation by 2015 . Nevertheless, two main issues have to be tackled in order to reach this goal. In most developing countries, and Brazil in particular, the first problem is the slow progress of sanitation and the second is the huge gap between urban and rural population for both water access and sanitation. The issue of access to water and sanitation services (WSS) in rural areas is worldwide. Among the largest disparities in WSS are those between urban and rural populations. For example, the urban-rural divide in drinking water is at its widest in sub-Saharan Africa, where 81 per cent of people in urban areas are served, compared with 41 per cent in rural areas (UNICEF, 2006).

In Brazil, the urban-rural disparities are especially striking as the water coverage is nearly universal in the urban areas and reaches only $57 \%$ in the rural areas, the coverage for sanitation is $75 \%$ in urban areas and $37 \%$ in rural areas. Therefore, the reduction of the WSS urban-rural disparities remains an essential challenge, fuelled by a very strong social demand.
In most developing countries, public authority awareness increases about WSS in rural areas (Akuoko-Asibey, 1996; Madulu, 2003; Mwendera, 2006). But studies or evaluation of the programs launched in order to tackle this issue remain very rare and significantly scarcer than the studies dealing with WSS in urban, poor areas.

Moreover, good water and sanitation services can play a decisive role in limiting rural migration and thus in fighting against the uncontrolled expansion of urban slums. In developing countries therefore, reducing the urban-rural divide for water supply and basic sanitation is an essential step for reaching sustainable development.

In the Brazilian State of Minas Gerais, in spite of global progress over recent years, access to water and sanitation services is still unacceptably poor in the north-eastern area of the State (IBGE, 2002). The sanitation situation is the worst with most municipalities presenting a sanitation ratio of approximately $40 \%$. The low level of WSS in Minas Gerais' poorest regions triggers a vicious circle of underdevelopment and low living standards.

It is frequently admitted that the lack of WSS is mainly linked to deficient water sector governance and not to technical problems (e.g. Mwanza, 2005; Cross and Morel, 2005). In many countries, water sector reforms aimed at improving WSS through a more efficient management structure, have therefore been implemented. "Good" governance comprises public sector management, accountability, transparency and availability of information. Among the essential issues embedded in the reform of water policy at a regional scale, the following are frequently mentioned: decentralization and subsidiarity, tariff design, public participation, accountability and evaluation, innovation in institutional and financial arrangements (e.g. Cross and Morel, 2005; Jones, 1998; Bakker, 2003, Jaglin, 2003). But good governance and improvement of WSS can only be achieved through a great diversity of possible arrangements, a topic which is still an item of active on-going evaluation and research (Garcia-Valiñas, 2005; Swatuk, 2005; Garcia-Valiñas, 2007; Nare et al., 2006; Heller, 2007). Several research studies analysing the impacts of internationalisation of feasible solutions also highlight the great diversity of the organisational and institutional solutions adopted by the developing countries (e.g. SchneierMadanes and de Gouvello, 2003). These studies, based on a bottom-up approach, insist on social learning paralleling the reforms. In the African and South American countries investigated, it took several years for the organizing authorities and the private companies to agree on their respective competences and duties, for the users to self organise and structure their claims and for the bodies in charge of the regulation to define a code of conduct (De Gouvello, 2003). These studies are very valuable in understanding the possible negative impacts on the cities, e.g. urban fragmentation (Jaglin, 2003) and potential conflicts embedded in various organisational and institutional solutions, the case of Buenos Aires being exemplary (Schneier-Madanes, 2003). 
Notwithstanding, the main learning of these studies is that each project presents territorial specificities and requires a specific evaluation framework. Moreover, the problematic is rather different in the rural areas where it is becoming obvious that the expected results are far from being achieved.

In all these studies, the lack of documentation on actual projects is also highlighted. There is an urgent need for effective models and tools that take the local context into account, which will enable deciders to implement water sector reforms that meet the real economic, political, sociological and environmental constraints (Cross and Morel, 2005).

It is now very important therefore to implement WSS projects and in parallel, to start a learning process aimed at better quantifying the actual costs and at testing the territorial solutions (Kauark-Leite, 2005). In this context, the main objective of the Vida no Vale project is to bring universal access to sanitation and water for the whole population of the region, inhabitants of both urban and rural areas alike. To fight against poverty and support sustainable development, it is essential to improve people's living conditions in rural as well as urban areas (Cross and Morel, 2005; Mwanza, 2005). The Vida no Vale project can be considered as a way to substantiate the universal right of access to water, warranted by the Brazilian constitution and to achieve one of the main United Nation Millennium Development Goals. The project, coordinated by SEPLAG (Secretaria de Estado de Planejamento $e$ Gestão, Minas Gerais' Secretariat of State for Planning and Management) and COPASA (Companhia de Saneamento de Minas Gerais, a mixed economy company, of which the State of Minas Gerais is the main shareholder), constitutes one of the most ambitious projects within the framework programme Mais saude para todos (More health for everybody) of the Minas Gerais government.

\section{The project area}

The project area of approximately $87000 \mathrm{~km}^{2}$, is located in the North-eastern part of the State of Minas Gerais (15$18^{\circ} \mathrm{S}, 40-45^{\circ} \mathrm{W}$ ) (Fig. 1). The climate is semi-arid, the mean temperature is approximately $21^{\circ} \mathrm{C}$ and the annual rainfall some $1000 \mathrm{~mm}$ (A.N.A, 2007). The rainfall is unreliable, occurring mainly in summer, and there is nearly no rain during the dry season, from June to September. The mean specific discharge of the principal rivers is about $6.81 \mathrm{~s}^{-1} \mathrm{~km}^{-2}$, varying between $1.71 \mathrm{~s}^{-1} \mathrm{~km}^{-2}$ and $231 \mathrm{~s}^{-1} \mathrm{~km}^{-2}$, indicating relatively adequate water resource availability (IGAM, 2006).

The project area is made up of three main river basins: those of the Jequitinhonha $\left(65851 \mathrm{~km}^{2}\right)$, Mucuri $\left(12765 \mathrm{~km}^{2}\right)$, and Saõ Mateus $\left(5682 \mathrm{~km}^{2}\right)$ rivers and three other smaller basins (Burahém, $325 \mathrm{~km}^{2}$; Jucuruçu, $712 \mathrm{~km}^{2}$ and Itanhém, $1519 \mathrm{~km}^{2}$ ). Only in the Jequitinhonha and the Mucuri basins is the environmental quality of the water bodies assessed through regular monitoring, designed at the State level since 1997 (IGAM, 2006). The survey con-

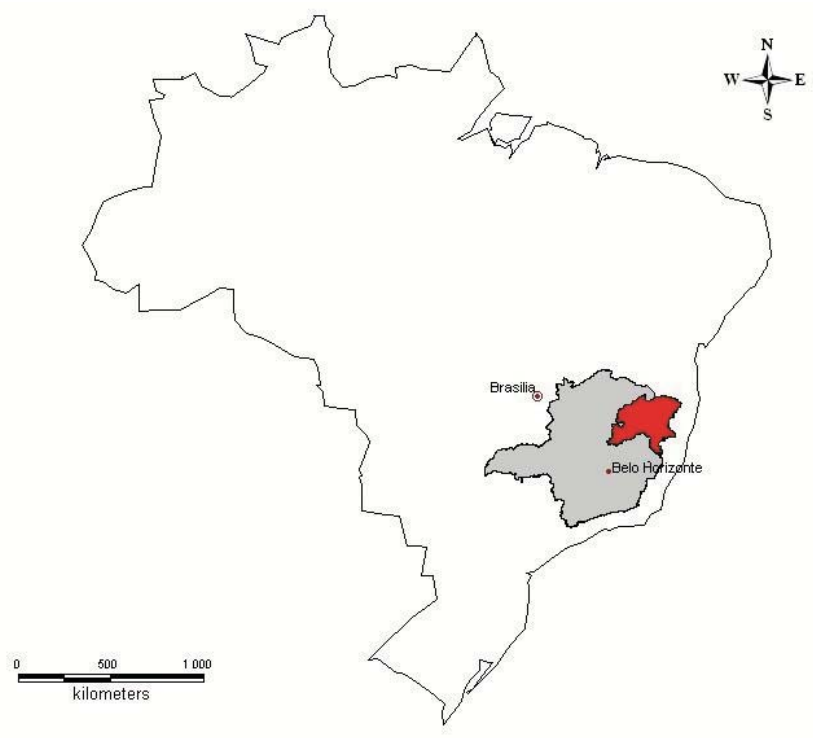

Fig. 1. Map of Brazil showing the project's region within the State of Minas Gerais. The project area is coloured in red.

sists of 4 campaigns per year at 13 sampling points located in the Jequitinhonha basin and 8 points in the Mucuri basin. As in most of the Brazilian water bodies, the worst pollutant parameter values are those for coliforms, indicating a widespread environmental problem due to untreated sewer discharge into the rivers (IGAM, 2006).

The project area consists of 92 Municipios $^{1}$ with a total estimated population of approximately 1.3 million in 2006, with 770000 inhabitants in the urban areas and 530000 in the rural areas. The 92 Municipios include 92 sedes, 72 distritos and 1800 localidades (Table 1). In the region, widespread poverty prevails, characterized by subsistence farming and high rates of rural-urban migrations. Living standards are low and the public health situation is very poor. In particular, the region is a focus of hyperendemic Schistosomiasis (Gazzinelli et al., 2006).

\section{The existing situation of WSS}

\subsection{WSS in Brazil}

Over the last decade, the institutional organisation of water and sanitation services in Brazil has been changing. At the beginning of the seventies, a national water supply and sanitation system, called PLANASA, was set up. In each Brazilian state, a water and sanitation company was created, for

\footnotetext{
${ }^{1}$ Brazil is a federal union where the Municipio is the smaller political-administrative unit. It is composed of the sede, the main city where most of the population lives, and the rural area which contains distritos, small secondary towns (100 to 3000 inhabitants), and localidades consisting of a few grouped houses.
} 
Table 1. Main features of the project area (from Kauark-Leite, 2005).

\begin{tabular}{ll}
\hline Total area & $86854 \mathrm{~km}^{2}$ \\
\hline Number of municipios & 92 \\
Number of distritos & 72 \\
Total population & 1265222 \\
Total population in the sedes & 752426 \\
Total population in the distritos & 512796 \\
Total urban population & 746481 \\
Total rural population & 518741 \\
Number of remote, rural inhabitants & 118000 \\
\hline
\end{tabular}

example COPASA in Minas Gerais. During this period, a huge migration flux of population occurred from the rural areas towards the cities (Heller, 2006). From 1970 to 2000, the Brazilian urban population nearly increased threefold, from 52 millions (56\% of the total population) to 138 millions $(81 \%)$.

Until 1985, only the state water companies could obtain federal financing for building and operating the water and sanitation systems. The state water companies generally operated under long-term concession contracts (usually 30 years) with the municipalities, which are legally in charge of the water and sanitation policies. The PLANASA system achieved a rapid but very heterogeneous expansion of WSS, fostering water supply but neglecting drainage and sanitation. Moreover, most of the PLANASA investment was concentrated in the larger cities, and within these cities, in the better-off sections of the population (Arretche, 2007). Presently, in Brazil, the water coverage is $80 \%$, with a rate of about $90 \%$ connection in the urban areas. The sewer coverage is $65 \%$, with a rate of $75 \%$ connection in the urban areas (IBGE, 2002).

About $80 \%$ of Brazilian municipalities joined the PLANASA system. In some other municipalities, municipal companies operated the WSS. In the remaining municipalities, the WSS management was linked to a Health Ministry entity, the National Health Foundation (FNS, Fundo Nacional de Saude). Services were operated by a municipal agency administratively, technically and financially autonomous, but largely supported by FNS administrative and technical assistance.

In the middle of the 80s, the PLANASA model started to break down when the Federal Government started to neglect its duty of regulation, leading to self-regulation by the water companies which defined their own goals and investment plans, without any control by either the licensing authority or the citizens. This deregulation resulted in the stagnation of WSS development (Parlatore, 2000). PLANASA's decline can be mainly explained by the very high inflation which occurred in Brazil during the 80s and turned the tariff structure unsustainable. Moreover, after the return to democracy, the decentralisation process promoted by the new 1988 constitution turned the highly centralized PLANASA system unsuitable and led to its extinction in 1992 (Seroa da Mota and Moreira, 2006; Sabbioni, 2008). From 1993, at the end of the concession licenses, some municipalities re-gained charge of WSS, creating municipal entities or contracting with a private company. The departure of some large municipalities from the PLANASA system resulted in a strong impact on the economic sustainability of many state water companies.

On the legislative side, the federal laws relative to water management have also significantly evolved during the last decade with two main laws being of significance to water management. The first one, the federal law 9433/1997 which underpins water resource management states as basic principles: sustainability, public participation and decentralization with water management established at the river basin level. The second law, the federal law $11445 / 2007$ is specific to overall sanitation services, particularly water supply and wastewater treatment. This law strengthens the principles embedded in the law of 1997 in an adapted way to WSS and focusses on different aspects of service provision. Subsidiarity, which is the principle stating that responsibilities have to be handled at the lowest competent level, is also embedded in this law. It also considers the association of municipalities in consortium, according to the federal law 11 107/2005, in order to provide water supply and sanitation services on a regional basis (Nascimento et al., 2007). Finally, in establishing a new contract for WSS, the law points out the importance of defining the objectives of the programme and the necessary separation between the levels of planning, regulation, operation and evaluation of results. In all those levels, public participation is a basic requirement.

Therefore since the nineties, the Brazilian WSS institutional model has been greatly diversified (A.N.A, 2007): investment sources, opening of company capital to private investors, management of systems by private operators, ...

\subsection{WSS in the project area}

In the Jequitinhonha, Mucuri and São Mateus valleys, a severe shortfall of WSS is evident. At present, about $65 \%$ of the population have access to some kind of water supply, $40 \%$ to a sewage system and $50 \%$ to a waste collection service (IBGE, 2002). These rates are significantly lower than the average values for Brazil and they illustrate very clearly the limits of the existing system, which neglects the rural areas and hinders overall sanitation development in the region.

Moreover, the data indicates only the number of inhabitants connected to a water network and a sewage network but do not give a precise idea of the quality of the services. The quality and reliability of WSS is often inconsistent, especially in remote communities. In most cases, there is no waste water treatment before release into receiving bodies. Moreover, in spite of the rural areas constituting about $41 \%$ 


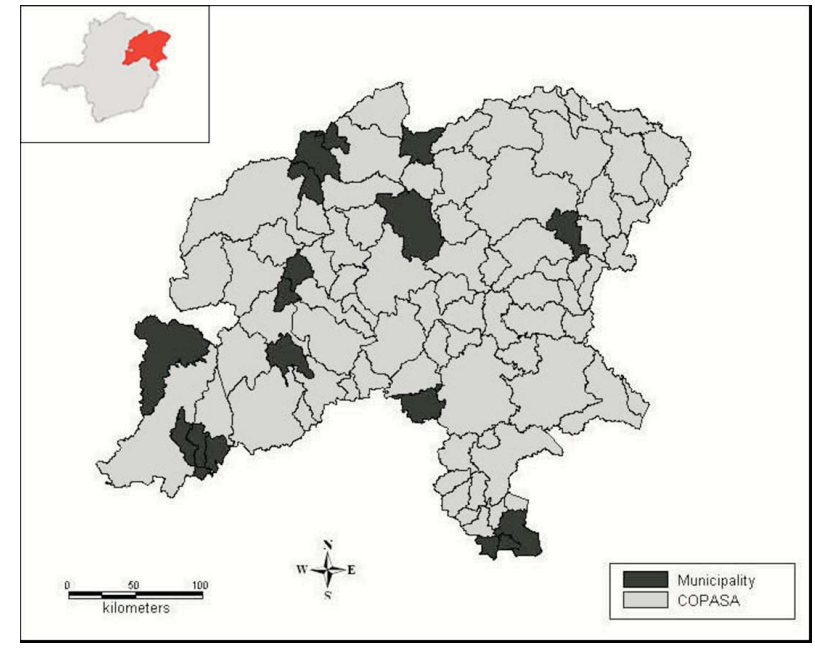

Fig. 2. Map of the project region showing the limits of the $92 \mathrm{mu}-$ nicipalities and indicating the WSS operator (COPASA in grey or Municipality in black) in the urban areas. In the upper left hand corner, the State of Minas Gerais where the project area is coloured in red (Redrawn from SEPLAG, 2007).

of the population of the whole region, statistical information is very scarce.

While some of the established water systems are managed by a municipal authority, most of them are managed by COPASA (Fig. 2). Irrespective of the management type COPASA or municipal authority - drinking water coverage reaches $98 \%$ in the urban areas but only $22 \%$ in the rural areas (Table 2). The few existing sewage systems are mainly managed by the municipalities. In spite of huge regional discrepancies, one single pricing scheme is implemented by COPASA for the whole State of Minas Gerais.

\section{The guiding principles of the project Vida no Vale}

In the poorest regions of Brazil, the water price is insufficient to cover WSS investment expenditure or to pay the operational expenditure in many cases. In the COPASA model, based on a single pricing structure for the whole State, linked with a mechanism of cross subsidy between the different categories of consumers, the deficit of the poorest is counterbalanced by the surplus afforded by the richest. To obtain the necessary financial support for improving WSS coverage, COPASA would have to increase the present prices, which are already very high, particularly because of the indirect costs due to the existing remote, centralized management ${ }^{2}$.

\footnotetext{
2The COPASA headquarter is located in Minas Gerais' capital, Belo Horizonte, $500 \mathrm{~km}$ (and about $10 \mathrm{~h}$ by road) from the project region. The most remote localidades are $800 \mathrm{~km}$ from Belo Horizonte.
}

Table 2. Main features of the water supply (a) and sanitation (b) services in the project region (from SEPLAG, 2007).

\begin{tabular}{|c|c|c|c|c|c|c|}
\hline \multicolumn{7}{|c|}{ (a) Water supply } \\
\hline \multirow{2}{*}{ Operators } & \multicolumn{3}{|c|}{ Sedes (urban) } & \multicolumn{3}{|c|}{ Distritos and localidades (rural) } \\
\hline & $\mathrm{n}^{*}$ & Population & $\mathrm{CR}^{* *}$ & $\mathrm{n}$ & Population & $\mathrm{CR}$ \\
\hline Municípal & 17 & 74286 & $95.6 \%$ & 1815 & - & - \\
\hline COPASA & 75 & 678140 & $98 \%$ & 38 & - & - \\
\hline TOTAL & 92 & 752426 & $97.8 \%$ & 1853 & 512796 & $21.9 \%$ \\
\hline \multicolumn{7}{|c|}{ (b) Sanitation } \\
\hline \multirow{2}{*}{ Operators } & \multicolumn{3}{|c|}{ Sedes (urban) } & \multicolumn{3}{|c|}{ Distritos and localidades (rural) } \\
\hline & $\mathrm{n}^{*}$ & Population & $\mathrm{CR}^{* *}$ & $\mathrm{n}$ & Population & $\mathrm{CR}$ \\
\hline Municípal & 85 & 524903 & $50.8 \%$ & 1850 & - & - \\
\hline COPASA & 7 & 227523 & $83.7 \%$ & 3 & - & - \\
\hline TOTAL & 92 & 752426 & $60.7 \%$ & 1853 & 512796 & $1 \%$ \\
\hline
\end{tabular}

* n: number of systems

** CR: Coverage rate

The key challenge of bringing sustainable, universal access to water in the region relies on a system design which would be able to support water and sanitation services not only in the main cities but also in the rural, remote areas. At the geographical scale of a large State such as Minas Gerais $\left(550000 \mathrm{~km}^{2}\right)$, a centralized water company could hardly work efficiently for the whole State. A sustainable solution would be to fit the project into a decentralizing framework. In the proposed system, a subsidiary of COPASA would be created in the project area which would be in charge of the management of WSS for the region. At a consistent geographical and hydrological scale, the subsidiary will implement a better adapted operational model and offer technological innovation. A critical failure would be to design a new system, serving only cities having a minimum number of inhabitants. Such a cut-off is sometimes considered, mainly for economic reasons but would have very negative economic and social impacts which would threaten the project's capacity for fighting poverty in the region. Firstly, it would affect the project's economic sustainability as it would not allow an effective regional cross subsidy. Secondly, it would impair the socially sustainable development of the region in reinforcing rural-urban migration, causing the uncontrolled spread of slums in the outskirts of the cities. An essential aspect of the project is to include the whole population, disregarding the size or remoteness of the settlement, but seeking adapted, non-conventional solutions for the isolated hamlets. On this basis, the subsidiary would implement a transparent regional cross-subsidy and a pricing structure based on the local capacity to pay instead of the existing single State-wide pricing structure. At a regional scale, it would be possible to hold the subsidiary accountable for fulfilling its contractual obligations in operating, maintaining, and expanding the water and sewage systems through management design that involves local social participation, and a regional information system. Local economic development, including the creation 
of micro-enterprises for operation and maintenance of the system would be supported. The initial human and material resources would be provided by the existing State water company and this would facilitate the sustainability of the project (Clements et al., 2006).

The major principles guiding the realisation of the Vida no Vale project can be summarized as follows:

- Public management, decentralization and subsidiarity

- The assets are provided by the State of Minas Gerais, based on national solidarity through federal or state taxes, or on international solidarity through development funds. These public investments would be valued by the positive externalities linked to WSS improvement;

- Decentralization will be made effective by creating a regional public subsidiary of the State water company, thus reducing costs due to the existing centralized system;

- Equity and sustainability

- No cut-off based on the number of inhabitants, would be considered in the system design. An adapted, non-conventional solution is proposed for every hamlet, independently of its size or its remoteness;

- Universal access to water and sanitation would be achieved through a price structure taking into account people's capacity to pay and providing, at no cost, a minimum water quantity $\left(3 \mathrm{~m}^{3} /\right.$ month) for the poorest households;

- The economic sustainability of the service would be based on a progressive price structure calculated to cover the functioning costs and the long-term maintenance requirements;

- Accountability and transparency

- Social participation in the management and the coproduction of the service are key points of the project design;

- The project execution would be assessed and a transparent evaluation of the project targets carried out by an independent team. In parallel, the ongoing project would be opened as a study site to research teams working in the field of water engineering and water policy.

- Integration

- Public health and the environmental quality of the water bodies would be significantly improved by the expansion of the sanitation services;
- Economic development in the region would be enhanced through the establishment of local small enterprises and co-operatives, to handle some aspects of the operations and maintenance of the system;

- Synergistic activities, in irrigation, public health, urban drainage, waste management and road maintenance, for example, would be fostered.

\section{The project structure}

Based on the above principles, the project has been divided into two stages. The first stage, which ran from January to November 2006, was made up of a feasibility study and the implementation of 9 pilot sub-projects. This first phase was primarily aimed at translating the principles from concept to action through field testing of concrete system designs and project improvements. The project's final implementation phase will run for five years, from 2007 to 2011.

\subsection{The feasibility study}

The feasibility study, conducted in 2006, was performed by SEPLAG and COPASA engineers and by consultants. It aimed at (1) analyzing and quantifying the supply and demand of WSS in the region; (2) investigating very accurately the WSS situation regarding the technical, management, tariff and regulation features; (3) analyzing the social, economic and environmental situation and public health aspects; (4) defining a new operational and institutional model for sustainable universal access to WSS.

\subsubsection{The supply and demand of WSS}

The supply and demand of WSS have been analyzed and the existing situation accurately assessed. For the $92 \mathrm{mu}-$ nicipalities, including urban and rural areas, a technical report has been established, which summarises the proposed interventions for water and sanitation systems and the associated costs. The technical design regards automation, including telemetry, remote monitoring and remote control, as key points in order to ensure operational functioning and cost reduction.

\subsubsection{The WSS diagnosis}

Regarding drinking water, most systems are supplied by surface water. It has been shown that in nearly all the sedes, drinking water services are working rather well. In the COPASA systems, the service quality is regularly controlled and fulfils the legal standards. However in most of the systems operated by the municipalities, the drinking water supply is very deficient. For sanitation, the whole coverage in the sedes, including sewer network or individual septic tanks, is about $60 \%$ although even when a network exists, collected sewage remains untreated. In that case, the sewer 
network may actually worsen local environmental and health problems owing to a point-concentrated pollution discharge. The installation of sewer networks without adequate sewage treatment cannot improve sustainably the sanitation service.

In $60 \%$ of the rural localidades no drinking water network exists and in most of them, no collective water supply is available. The drinking water is supplied by individual, uncontrolled systems or by tank trucks. In these areas, water is not treated and its quality is very poor. Sanitation is mainly by waste pit or septic tank but only an estimated $30 \%$ of the tanks are in working condition. No draw-off of the pits is carried out, so they are periodically backfilled, and a new waste pit dug in a new location. A breach in the pit sometimes occurs and the sewage escapes into the courtyard or into the ground, contaminating the water table. In many households, no toilets are available. In these houses, the Vida no Vale project intends to install a sanitary unit including a toilet and a septic tank although it is not planned that these remote households will be linked to a network. Efficient, nonconventional systems will be introduced instead, including for example, a well fitted septic tank design in combination with a controlled, adapted cleaning and maintenance service.

For drinking water supply, improvements concerning the water quality and the sustainability of the service will be achieved through the following progressive steps: expanding equipment automation where possible, digitization and updating of the cadastral registers, increase in preventive maintenance, definition of the goals to be attained with benchmarking of WSS and introduction of social control.

In the systems operated by the municipalities, much operational progress is required: development of household water metering; better control of the quality and continuity of the service; reducing losses through leakage; maintenance of equipment and buildings; improvement of worker training, etc.

Regarding the pricing structure for water and for sanitation, the COPASA system contains five categories of consumers: social, residential, commercial, public entities, industrial. Prices rise with volumetric increases in use. For the social rate, covering approximately $12.5 \%$ of households, a discount is granted when the built area is less than $44 \mathrm{~m}^{2}$ and the water consumption is less than $15 \mathrm{~m}^{3} /$ month. A negative point of the social rate refers to the minimum water quantity of $6 \mathrm{~m}^{3} /$ month, which is charged even if the household consumption is lower. Therefore, households consuming less than $6 \mathrm{~m}^{3} /$ month pay a higher rate, which contradicts the goal of beneficiating the poorest. The sanitation tariff is $60 \%$ of the drinking water tariff. In the systems operated by the municipalities, the water is generally free although in some cases, a fixed price is paid irrespective of the water volume used (which in any case is generally not measured).

The willingness to pay for an improvement of WSS of the project region population has been accurately assessed through a contingent valuation method (Briscoe et al., 1990; Faria, 1995) based on a sample of 2500 households, $50 \%$ in the sedes and 50\% in the rural area of the same municipalities. A different focus of investigation was established for the rural and urban samples: in the rural area, the analysis concerned the improvement of the drinking water service and the implementation of regular cleaning of septic tanks. In the sedes, the improvement of sewage collection and treatment or sewage treatment implementation has been the main focus. This study provided the monetary values of the local willingness to pay of the different household categories and for the different type of WSS. The socio-economic features of each group, notably the income distribution, provide useful data for detailing the new system design.

\subsubsection{The new system design}

The main challenge of the project is to define an operational model for sustainable and universal access to WSS, not only in the region's urban areas, but also in the small remote rural communities. At this scale, traditional technical approaches can be too expensive and up to now, no existing institutional model has been successful in solving the problem. In this context, the proposed design intends that a new regional enterprise, the subsidiary of COPASA previously mentioned, would integrally operate WSS. Moreover, all COPASA employees will retain their employment and no break would occur in the services. Simultaneously with the creation of the subsidiary, its goals, indicators and evaluation rules would be specifically defined.

For water supply and sanitation in the sedes, the new model would not be very different from the current one. The main innovations will be found in the rural communities where new services (e.g. building and maintenance of septic tanks) would appear and where the labour cost could decrease by fostering the co-production of WSS. In the new structure, the number of water and sanitation systems will progressively rise from 100 currently to about 2000, at completion. Partnerships will be organized at complementary levels: (1) at the localidade level, partnership with local labour for the simplest operational activities and direct commercial activities; (2) at the municipal or micro-regional level, partnership with skilled labour for the maintenance of the equipment and for bill payment and (3) at the regional level of the subsidiary, the maintenance and repair of complex equipment which cannot be carried out at the lowest levels. The subsidiary is accountable for the services and is therefore in charge of contracting the skilled labour at the lowest levels.

Most operational activities will be conducted at the local and municipal levels. Local labour participation should lead to a better knowledge of the situation, allowing appropriate and faster interventions. The productivity and the efficiency of the system will be optimized by reducing logistic and transport costs. At the first and second levels, the partnership organization will enhance the creation of local associations, 


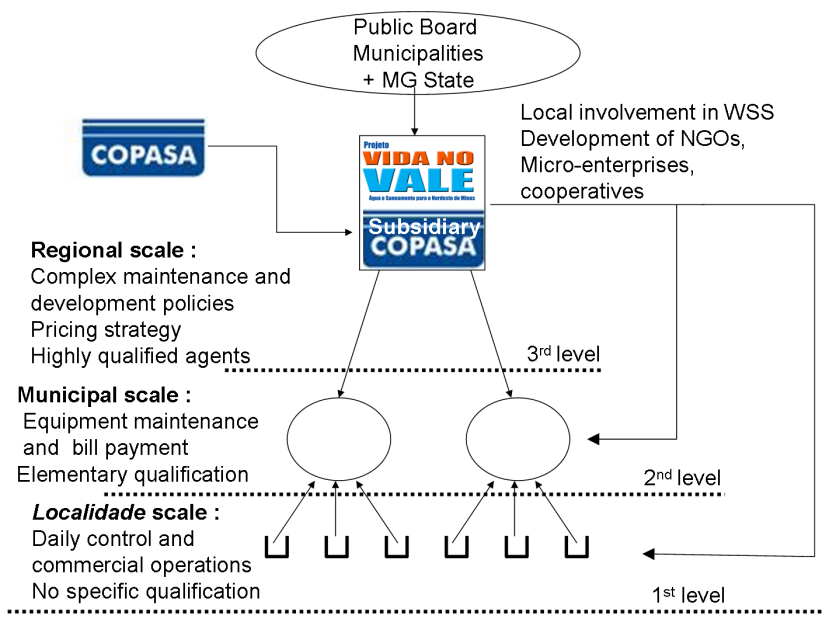

Fig. 3. Sketch of the new institutional model illustrating the links between the public board (municipalities + Minas Gerais State), the regional subsidiary and COPASA. The institutional design is presented in more detail in Sect. 6.1.3 (redrawn from SEPLAG, 2007).

cooperatives or micro-enterprises contributing to the development of the local economy.

The second institutional element of the new WSS management is the creation of a public consortium, bringing together the 92 municipalities of the project area and the State of Minas Gerais. The regional subsidiary, contracted by the consortium, will operate WSS within the region (Fig. 3). The consortium will be in charge, for example, of defining a specific regional pricing scheme. This organization, associating public participation, will help in legitimizing decisions and in optimizing the synergistic effects of the joint management by the stakeholders.

\subsection{The pilot sub-projects}

The pilot sub-projects have been implemented in nine municipalities within the region which presented the lowest WSS coverage and the lowest HDI (Human Development Index), a summary composite index that measures three basic aspects of human development: longevity, knowledge, and a decent standard of living (UNDP, 2004). Amongst the nine municipalities, the drinking water is supplied by COPASA in the sedes of seven of them. In the two other sedes and in all the rural communities, a municipal authority is in charge of the water supply. A sanitation service is present in only one sede (COPASA). The pilot sub-projects, whose combined total cost is approximately 32 millions $\mathrm{R} \$(\approx 12$ millions $€)$ (SEPLAG, 2007), were aimed at testing and improving the whole project design, particularly regarding organizational and technological innovations.

A complete diagnosis of water supply and sanitation has been accurately established for 23 hamlets in these municipalities. Different technological alternatives and innovative
Table 3. Selected criteria for the project evaluation (from Clements et al., 2006).

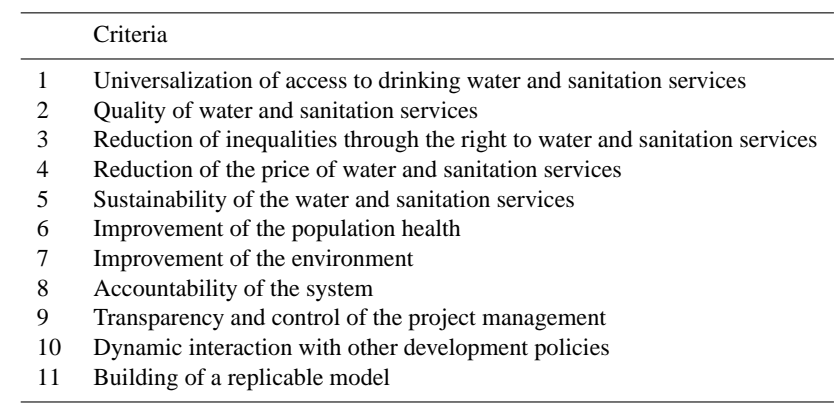

solutions have been designed and the required infrastructure (e.g. sanitary units, sewer networks, storage tanks, waste water treatment plants) is being built.

One of the main targets of the pilot sub-projects was to investigate the adapted institutional structure for the implementation of the project final design, namely the juridical structure of the joint management between the municipalities, the State and the COPASA subsidiary.

Another important aspect dealt with defining and testing ways for local micro-entrepreneurs to participate in operating the local water and sanitation services (e.g. connecting houses to the network, installing water meters), development of a methodology for educating local skilled labour, educational development of the local population especially in the primary schools, involvement of the local population in goal definition, in the survey of building sites and in operations. For example, within the pilot-projects, 170 persons have received specialist training for teaching environmental knowledge to the population. This has resulted in the definition of a generic methodology for public participation.

\section{Research objectives corresponding to the project eval- uation process}

A main innovation of the project lies in the process of continuous assessment and possible adjustment of its technical, institutional, and economic features. The project evaluation framework is already designed (Clements et al., 2006). However, this process of permanent assessment requires a previous acceptance by the project stakeholders of the evaluation criteria and the monitoring guidelines. In the next paragraph, we propose what should be the criteria for the project evaluation and monitoring (Table 3). Some of those criteria may require further research development, as also discussed.

The eleven criteria for the project evaluation (Clements et al., 2006) roughly correspond to the identified targets previously presented: (1) Universalization of access to improved water and sanitation services; (2) Quality of water and sanitation services; (3) Reduction of historic inequalities through 
the right to water and sanitation services; (4) Reduction of the price of water and sanitation services; (5) Sustainability of the water and sanitation services; (6) Improvement of the health of the beneficiary population; (7) Improvement of the environment by better wastewater management; (8) Accountability of the system through the building of institutions at the municipal and regional levels; (9) Transparency and control of the project management; (10) Dynamic interaction with other development policies; (11) Building of a replicable model (financial, operational, technical and institutional) for substantiating the right to water and sanitation services in other developing countries.

Some indicators can easily and obviously be implemented in order to monitor each of the evaluation criteria. Criteria $1,2,4,5$ and 9 do not require further investigation to be substantiated by indicators which can be readily monitored. For instance, criterion $n^{\circ} 1$ (universalization of access) can be catered for by two strong and obvious indicators: the number of persons who gain access to treated water, the number of persons who gain access to sanitation services. The baseline here is well-known: approximately 400000 persons do not currently have access to treated water while 800000 persons lack sewage services. Finding obvious indicators becomes a more complicated task in the case of criterion $n^{\circ} 3$. The pricing structure constitutes an element in the reduction of the historic inequalities through the right to water and sewage service but there is obviously a need for an accurate methodology to assess the effects of such a pricing scheme on inequalities. Other parameters, such as household size, can be introduced in order to explain the economic fluxes within the various communities.

Criterion $n^{\circ} 6$ (Health) is problematic mainly due to poor reliability of available data. Existing morbidity and mortality data for the project area are known to be incomplete, so impact measures based on these data will underestimate the project's health impacts. Criterion $n^{\circ} 7$ (Environment) can on the one hand be easily translated into obvious indicators using existing Federal standards and recommended systems of monitoring. On the other hand, there are many uses requiring water quality standards which are far from being embedded in the regulation. An in-depth investigation into the impacts of the new sanitation systems on the water bodies at different scales would be of a great importance for the evaluation of the positive externalities of the project.

However, the most problematic are no doubt criteria $n^{\circ} 8$ and 10 . Concerning criterion $\mathrm{n}^{\circ} 8$, the organisation of the existing institutions and the creation of new institutions in order to hold the project operator accountable are in progress. The stakeholders in charge of raising and maintaining concern for the management of the water services in civil society (especially in NGOs such as handcrafts or agricultural trade or women's organizations) are yet to be defined. For such issues, qualitative studies are necessary, using observation of meetings, interviews with stakeholders and the general public, in some predefined sampled municipalities. The re- sponsibilities and compulsory reports of the project operator to the municipalities and sub-municipal governments must also be defined. The economic and social benefits of the coproduction of WSS by small entrepreneurs comprise another issue which will need thorough investigation using sociological tools. This issue is essentially concerned with accountability. It is important to verify how establishing local and regional small enterprises for technical tasks such as leak and pump repair, meter reading, septic pit sludge removal, and (possibly) bill collection, can have a positive impact on the control of the operator by the users.

The development of synergistic activities (criterion $\mathrm{n}^{\circ} 10$ ) is another issue of concern to social science researchers working on developing countries. Improvement of water supply and sewage is part of a global strategy of development including drainage, road infrastructure, waste management,... and the project manager lacks methodologies enhancing the activation of the links between those policies.

Indeed, if all these challenges are successfully achieved, the Vida no Vale project will be considered successful according to criterion $\mathrm{n}^{\circ} 11$ : Building of a replicable model (financial, operational, technical and institutional) for substantiating the right to water and sewage service in other developing countries.

\section{Conclusions}

The objective of the Vida no Vale project is to bring universal access to sanitation and water for the whole population of the Jequitinhonha, Mucuri and São Mateus river basins, inhabitants of the urban and rural areas alike. For this purpose, the proposed system is based on the guiding principles of decentralization and subsidiarity. Designed at a consistent geographical and hydrological scale, it includes as a keystone element the creation of a regional subsidiary of the existing state water company. At this regional level, effectiveness of WSS can be achieved through an economy of scale. Technical support can be coordinated and organized at the regional level, based on skilled labour available in the region and not in each municipality, the consistency of the equipment fleet making easier its maintenance and renewal.

The institutional organisation relies on the creation of a public consortium consisting of the 92 municipalities of the project region and of the State of Minas Gerais. This public board will support the joint management of the stakeholders, the public participation in the production and control of WSS and an independent, transparent evaluation of the project achievements. The sub-contracting of micro-entrepreneurs will foster the implementation of new services such as septic tank building and maintenance; it will also enhance local economic development and the reduction of operational costs. 
The project consisted in a first step, run in 2006 which included a feasibility study and the implementation of pilot sub-projects. A second phase corresponding to the project's final implementation will run for five years, from 2007 to 2011.

The key points of the feasibility study, concluded at the end of 2006, are (1) the definition of the supply, the demand and the capacity to pay for the water services; (2) the diagnosis of the patrimonial assets and of the management system; (3) the assessment of the necessary amount of investment; and (4) the definition of an innovative operational model and a sustainable management system, including civil society participation.

The main features of the Vida no Vale project are being tested in the pilot sub-projects and implemented in the urban and rural areas of municipalities chosen for their low HDI and lack of WSS. These pilot sub-projects are aimed at adjusting and improving the institutional design, the subcontracting of local labour, the environmental education of the population and public participation.

The project economic sustainability is achieved by assuming that the assets have to be public and by a progressive price structure calculated to cover the operational expenses and the long-term maintenance requirements. A private partnership with local, small enterprises is intended for handling technical tasks at reduced cost. The technical design involves innovative technologies (e.g. automation, telemetry, remote control,...), as key points for improved operational functioning and cost reduction. Essential innovative features appear at the institutional level: decentralization is achieved by creating a regional subsidiary of the existing water company and by attempting a smooth transition from the prior management to management under the project. Public participation in the production and control of WSS as well an independent, transparent evaluation of the project achievements are part of the project design. At a general level, through this comprehensive, innovative design, the Vida no Vale project could be considered replicable to other poor, rural areas in developing countries by addressing key rural WSS challenges.

Acknowledgements. The authors thank Jean-Marie Mouchel for opening up the Congress "Man and River Systems" to the presentation of the project Vida no Vale. Nilo Nascimento and André Leite-Guerra, respectively professor and civil engineering student at UFMG, are greatly acknowledged for their helpful contribution. A. Mauro, engineer at COPASA is warmly acknowledged for his participation in the initial project design. B. de Gouvello and B. Tassin (Cereve) are thoroughly acknowledged for their critical and constructive reading of the paper. The authors also express their gratitude to J. Gedge for the revision of the English text.

Edited by: S. Barles

\section{References}

Akuoko-Asibey, A.: A summative evaluation of a rural water supply programme in Ghana, Applied Geography, 16, 243-256, 1996.

Alves, D. and Belluzzo, W.: Infant mortality and child health in Brazil, Economics \& Human Biology, Special Issue on Child Health in Latin America, 2(3), 391-410, 2004.

A.N.A. (Agencia Nacional de Agua): GEO Brasil Recursos Hidricos, Brasilia, Brazil, 2007.

Arretche M.: Water supply and sanitation, http://www.mre.gov.br/ cdbrasil/itamaraty/web/ingles/economia/saneam/apresent/index. htm, 2007.

Bakker, K. J.: From public to private to mutual? Restructuring water supply governance in England and Wales, Geoforum, 34, 359-374, 2003.

Briscoe, J., de Castro, P. F., Griffin, C., North, J., and Olsen, O.: Toward Equitable and Sustainable Rural Water Supplies: A Contingent Valuation Study in Brazil, World Bank Econ Rev, 4, 115134, 1990.

Castro J. E.: Poverty and citizenship: Sociological perspectives on water services and public-private participation, Geoforum, 2007

Clements, P., Chianca, T., Deroubaix, J. F., and Vinçon-Leite, B.: Monitoring and Evaluation System for the Vida no Vale Project, SEPLAG, Belo Horizonte, Brazil, 2006

Cross, P. and Morel A.: Pro-poor strategies for urban water supply and sanitation services delivery in Africa, Water Science and Technologies, 51(8), 51-57, 2005

De Gouvello, B.: Les multiples visages de la réorganisation des services d'eau dans les villes argentines, in Eaux et Réseaux, Les défis de la mondialisation, 235-252, Schneier-Madanes and de Gouvello eds., IHEAL, Paris, 2003.

Faria, E. D.: Avaliação contingente em projetos de abastecimento de água, Modernização do setor saneamento: Brasilia, Ministerio do Planejamento e Orçamento. Secretaria de Politica Urbana. Instituto de Pesquisas Econômicas e Aplicadas, 122 p., 1995.

Garcia-Valiñas, M.: Efficiency and Equity in Natural Resources Pricing: A Proposal for Urban Water Distribution Service. Environmental and Resource Economics, 32(2), 183-204, 2005.

Garcia-Valinãs, M.: What level of decentralization is better in an environmental context? An application to water policies, Environmental and Resource Economics, 38(2), 213-229, 2007.

Gazzinelli, A., Velasquez-Melendez, G., Crawford, S., LoVerde, P. T., Correa-Oliveira, R., and Kloos, H..: Socioeconomic determinants of schistosomiasis in a poor rural area in Brazil, Acta Tropica, 99(2-3), 260-271, 2006.

Heller, L.: Different approaches in analyzing water governance: implications to the case of Belo Horizonte, Brazil, First SWITCH scientific meeting, Birmingham UK, 2007.

Heller, L.: Accesso aos serviços de abastecimento de agua e esgotemento sanitario no Brasil: Considerações historicas, conjunturais e prospectivas. Centre for Brazilian Studies, Oxford UK, 2006.

Instituto Brasileiro de Geografia e Estatistica (I.B.G.E).: Pesquisa nacional do saneamento básico 2000, Brazil, 2002.

Instituto Mineiro De Gestão Das Aguas (IGAM): Monitoramento das aguas superficiais na bacia do Rio Jequitinhonha em 2005, Belo Horizonte, Brazil, 2006.

Jaglin, S.: L'eau potable dans les villes en développement: les modèles marchands face à la pauvreté, Revue Tiers Monde, XLII(166), 275-303, 2001. 
Jaglin, S.: Les échelles des réformes des services urbains de l'eau: L'exemple de la Namibie, in Eaux et Réseaux, Les défis de la mondialisation, 143-164, edited by Schneier-Madanes, G. and de Gouvello, B., IHEAL, Paris, 2003.

Jones, M.: Restructuring the local state: economic governance or social regulation?, Political Geography, 17(8), 959-988, 1998.

Kauark-Leite, L. A.: Un nouveau modèle de partenariat publicprivé pour les services d'eau des régions défavorisées, Paris, France, 2005.

Kauark-Leite, L. A.: Estudo de viabilidade para universalização dos serviços de água e esgoto no nordeste de Minas Gerais: Jequitinhonha, Mucuri e São Mateus, SEPLAG, COPASA, Belo Horizonte, Brazil, 2005.

Kauark-Leite, L. A.: Projeto Vida No Vale - Versão curta, Belo Horizonte, Brazil, 2006.

Madulu, N. F.: Linking poverty levels to water resource use and conflicts in rural Tanzania. Physics and Chemistry of the Earth, Parts A/B/C, 28, 911-917, 2003.

Mwanza, D. D.: Promoting good governance through regulatory frameworks in African water utilities, Water Sci. Technol., 51(8), 71-79, 2005

Mwendera, E. J.: Rural water supply and sanitation (RWSS) coverage in Swaziland: Toward achieving millennium development goals. Physics and Chemistry of the Earth, Parts A/B/C Water for Sustainable Socio-Economic Development, Good Health for All and Gender Equity, 31, 681-689, 2006.

Nare, L., Love, D., and Hoko, Z.: Involvement of stakeholders in the water quality monitoring and surveillance system: The case of Mzingwane Catchment, Zimbabwe, Phys. Chem. Earth, Part A/B/C, 31(15-16), 707-712, 2006.

Nascimento N. O., Knauer S., and Champs J. R.: Urban Storm Water Management in the Belo Horizonte area, Legislative and strategic structures. SWITCH internal report, Belo Horizonte, Brazil, 2007.
Parlatore, A. C.: A Privatização do Setor de Saneamento no Brasil, in: A Privatização no Brasil: O Caso dos Serviços de Utilidade Pública: Rio de Janeiro, edited by: Pinheiro, A. C. and Fukasaku, K., BNDES, 2000.

Rosado, M. A., Cunha-E-Sa, M. A., Ducla-Soares, M. M., and Nunes, L. C.: Combining averting behavior and contingent valuation data: an application to drinking water treatment in Brazil, Environ, Develop, Econom,, 11, 729-746, 2006.

Sabbioni, G.: Efficiency in the Brazilian sanitation sector: Utilities Policy, 16, 11-20, 2008.

Schneier-Madanes G.: Conflits de l'eau à Buenos Aires: les enjeux urbains, in: Eaux et Réseaux, Les défis de la mondialisation, 183-196, edited by: Schneier-Madanes, G. and de Gouvello, B. IHEAL, Paris, 2003.

Secretaria de Estado de Planejamento e Gestão (SEPLAG): Vida no Vale, synthesis booklet, Belo Horizonte, Brazil, 2007.

Seroa da Motta, R., and Moreira, A.: Efficiency and regulation in the sanitation sector in Brazil: Utilities Policy, 14, 185-195, 2006.

Soares, R. R.: Health and the evolution of welfare across Brazilian municipalities, Journal of Development Economics, 84(2), 590 608, 2007.

Swatuk, L. A.: Political challenges to implementing IWRM in Southern Africa, Phys. Chem. Earth, 30(11-16), 872-880, 2005

UNICEF: Progress for children. A report card on water and sanitation. New York, 2006.

United Nations: Millennium Summit recommendations. Heads of State Millenium Summit, New York, USA, 2000.

United Nations: United Nations Millennium Declaration, A/RES/55/2, New York, 2000.

United Nation Development Program (U.N.D.P.): Technical note 1 in Human development report 2004, New York, USA, 2004. 